\title{
Flotation-Calcination-Magnetic Separation Hybrid Process for Concentration of Rare Earth Minerals Contained in a Carbonatite Ore
}

\author{
Tesfaye Negeri \\ Natural Resources Canada, CanmetMINING, Ottawa, Canada \\ Email: tesfaye.negeri@canada.ca
}

How to cite this paper: Negeri, T. (2021) Flotation-Calcination-Magnetic Separation Hybrid Process for Concentration of Rare Earth Minerals Contained in a Carbonatite Ore. Journal of Minerals and Materials Characterization and Engineering, 9, 271-289. https://doi.org/10.4236/jmmce.2021.93019

Received: December 30, 2020

Accepted: May 24, 2021

Published: May 27, 2021

Copyright $\odot 2021$ by author(s) and Scientific Research Publishing Inc. This work is licensed under the Creative Commons Attribution International License (CC BY 4.0).

http://creativecommons.org/licenses/by/4.0/

\begin{abstract}
A hybrid process consisting of flotation and magnetic separation has been developed to concentrate multi-phase rare earth minerals associated with a carbonatite ore that contains a significant amount of niobium. The deposit is known to contain at least 15 different rare earth minerals identified as silicocarbonatite, magnesiocarbonatite, ferrocarbonatites, calciocarbonatite, REE/Nb ferrocarbonatite, phosphates and niobates. Although no collector exists to float all the different rare earth minerals, the hydroxamic acid-based collectors have shown adequate efficiency in floating most of these minerals. $92 \%$ recovery of total rare earth oxide (TREO) and niobium in 45\% mass was possible at $\mathrm{d}_{80}$ of $<65$ microns grind size. It was also possible to reduce the mass pull to $28 \%$, but TREO and Nb's recovery dropped to $85 \%$. Calcination of the concentrate followed by quenching and fine grinding to $<25 \mu \mathrm{m}$ allowed upgrading the flotation concentrate by magnetic separation. It was demonstrated that at least $87 \%$ TREO and $85 \% \mathrm{Nb}$ could be recovered in $16 \%$ of the feed mass. The paper discusses the overall concept of the flowsheet and the experimental strategies that led to this process.
\end{abstract}

\section{Keywords}

Flotation, Calcination of Rare Earth Flotation Concentrate, Magnetic Separation

\section{Introduction}

Rare earth elements (REEs) include the fifteen lanthanides, yttrium and scandium. They are found in more than 250 minerals, worldwide [1]. However, only about 60 of them contain REEs in significant amounts to warrant extracting. 
Over $95 \%$ of the world's rare earth oxides (REOs) come in the form of three minerals [2] [3]), namely bastnaesite ( $\mathrm{Ce}, \mathrm{La}, \mathrm{Y}) \mathrm{CO}_{3} \mathrm{~F}$, monazite ( $\mathrm{Ce}, \mathrm{La}, \mathrm{Nd}$, Th) $\mathrm{PO}_{4}$ and xenotime $\mathrm{Y}(\mathrm{PO})_{4}$. An estimated $51.4 \%$ of global REO resources are hosted by carbonatite deposits [4]. Any one of the REEs, or commonly all of them, can be found in these deposits. As the demand for REEs currently considered critical (Nd, Eu, Tb, Dy and Y) increases due to the ever-increasing applications in advanced technologies, many deposits containing other forms of REE minerals will have to be developed. REE minerals are extensively dispersed and intergrown with several oxides, silicates, carbonates, and phosphate minerals. Consequently, it is possible to liberate them only at fine grinding and is thus difficult to separate and produce high-grade rare earth mineral concentrates. Most of these minerals contain other important elements such as tantalum (Ta), niobium $(\mathrm{Nb})$, uranium $(\mathrm{U})$, and thorium $(\mathrm{Th})$ in varying quantities. REE minerals in the same ore may exist as carbonates, fluorocarbonates, niobates, silicates, phosphates etc., in association with gangue minerals belonging to different mineralogical groups.

Classification of REE deposits based on their mineralogy is still a work in progress. The U.S. Geological Survey classification in 2013 consisted of 34 different mineral deposits [5]. The two most important subclasses of alkaline rocks concerning REE deposits are the carbonatites and peralkaline rocks. At present, mineral deposits related to carbonatites account for most REEs production [5]. The most famous examples of carbonatite REE deposits are the Bayan Obo deposit in Inner Mongolia (China), and the Sulphide Queen Carbonatite of the Mountain Pass district in California. The only two significant mines outside China: Mt. Weld and Mountain Pass (although production is currently on hold) are carbonatite-type deposits. The International Union of Geological Sciences (IUGS) system of igneous rock classification defines carbonatites as having more than $50 \%$ of primary carbonate minerals, such as calcite, dolomite, and ankerite, and less than $20 \% \mathrm{SiO}_{2}$. Carbonatite REE deposits are enormously enriched in light REEs, particularly lanthanum, cerium, and neodymium.

Understanding each class of the REE mineral deposits' mineralogical characteristics is critical for determining the most suitable processing and extraction options. It is not uncommon to have several different mineralogical compositions within one deposit. An excellent example of this case is the Montviel REE deposit located in Quebec, Canada, which is the subject of this research and paper. Unlike most precious metals and base metal ores, where separation involves only a few minerals, the beneficiation of rare earth ores requires selective separation of a host of REE-bearing minerals (Table 1), each of which occurs in small quantities.

The Montviel deposit belongs to the carbonatite class of deposits. Its complex mineralization consists of silicocarbonatite, magnesiocarbonatite, ferrocarbonatites, calciocarbonatite, apatite-bearing and $\mathrm{REE} / \mathrm{Nb}$ ferrocarbonatite. A detailed mineralogical study by SGS-Lakefield identified the main REE-minerals as hua- 
nghoite and cebaite, which belong to the bastnaesite-synchysite family of fluoro-carbonate minerals where pyrochlore is the main Nb-bearing mineral. A recent study by Nadeau et al. [6] did not identify any REE fluorocarbonate, bastnaesite-(Ce), at the Montviel deposit. They stated the identification of REE carbonates and fluorocarbonates was challenging. Nevertheless, the REE minerals positively identified are shown in Table 1.

Mineralogical analysis of the ore sample used in this investigation revealed that carbonate minerals shown in Table 2 account for over $90 \%$ of the ore sample. Other minor gangue minerals present in the ore are listed in Table 3. The relative abundance of major minerals as determined by XRD and image analysis is shown in Table 4. The dominant gangue minerals are ankerite/dolomite (74.7\%), siderite $(9.10 \%)$, quartz $(4.80 \%)$ and calcite $(3.70 \%)$. The assay for the head sample is shown in Table 5.

The ore was selected for in-depth mineral processing research primarily for its complexity and inadequate response to standard beneficiation methods such as flotation, magnetic and gravity separations. It represents the most important class of primary $\mathrm{RE}$ deposit as a carbonatite ore, the only type producing rare earth elements to date.

Table 1. Minerals known to contain REEs and Nb in the Montviel ore deposit.

\begin{tabular}{|c|c|c|}
\hline Mineral & Formula & S.G. \\
\hline Allanite-(Ce) & $\mathrm{Ca}_{1.26} \mathrm{Ce}_{0.74} \mathrm{Al}_{1.83} \mathrm{Fe}_{1.17}-\left(\mathrm{SiO}_{4}\right)_{3}(\mathrm{OH})$ & $3.3-4.2$ \\
\hline Ancylite-(Ce) & $\mathrm{Sr}(\mathrm{Ce}, \mathrm{La})\left(\mathrm{CO}_{3}\right)_{2}(\mathrm{O} . \mathrm{H}.) \cdot \mathrm{H}_{2} \mathrm{O}$ & 3.9 \\
\hline Burbankite & $(\mathrm{Na}, \mathrm{Ca})_{3}(\mathrm{Sr}, \mathrm{Ba}, \mathrm{Ce})_{3}\left(\mathrm{CO}_{3}\right)_{5}$ & 3.5 \\
\hline Carbocernite & $(\mathrm{Na}, \mathrm{Ca})(\mathrm{Sr}, \mathrm{REE}, \mathrm{Ba})\left(\mathrm{CO}_{3}\right)_{2}$ & \\
\hline Cebaite & $\mathrm{Ba}_{3} \mathrm{Ce}_{2}\left(\mathrm{CO}_{3}\right)_{5} \mathrm{~F}_{2}$ & 4.8 \\
\hline Cordylite & $(\mathrm{Na}, \mathrm{Ca}) \mathrm{Ba}(\mathrm{REE}, \mathrm{Sr})\left(\mathrm{CO}_{3}\right)_{4} \mathrm{~F}$ & 4.4 \\
\hline Ewaldite & $(\mathrm{Ba}, \mathrm{Sr})(\mathrm{Ca}, \mathrm{Na}, \mathrm{REE}, \mathrm{Y})\left(\mathrm{CO}_{3}\right)_{2}$ & 3.3 \\
\hline Huanghoite & $\operatorname{BaRE}\left(\mathrm{CO}_{3}\right)_{2} \mathrm{~F}$ & 4.6 \\
\hline Kukharenkoite-(Ce) & $\mathrm{Ba}_{2} \mathrm{REE}\left(\mathrm{CO}_{3}\right)_{3} \mathrm{~F}$ & 4.6 \\
\hline Monazite-(Ce) & $(\mathrm{Ce}, \mathrm{La}, \mathrm{Nd}, \mathrm{Th})\left(\mathrm{PO}_{4}\right)$ & $4.6-5.7$ \\
\hline Qaqarssukite-(Ce) & $\mathrm{Ba}(\mathrm{Ce}, \mathrm{REE})\left(\mathrm{CO}_{3}\right)_{2} \mathrm{~F}$ & 4.6 \\
\hline Synchysite & $(\mathrm{CaREE})\left(\mathrm{CO}_{3}\right)_{2} \mathrm{~F}$ & 4.21 \\
\hline Xenotime-(Y) & $\mathrm{YPO}_{4}$ & $4.4-5.1$ \\
\hline Parisite & $\mathrm{CaCe}_{2}\left(\mathrm{CO}_{3}\right)_{3} \mathrm{~F}_{2}$ & 4.4 \\
\hline Petersenite (Ce) & $\mathrm{Na}_{4} \mathrm{Ce}_{2}\left(\mathrm{CO}_{3}\right)_{5}$ & 3.9 \\
\hline Barium-Strontium & BaSrNaREE Phase REE & \\
\hline Apatite & $\mathrm{Ca}_{5}\left(\mathrm{PO}_{4}\right)_{3}(\mathrm{OH}, \mathrm{F}, \mathrm{Cl})$ & 3.1 \\
\hline Pyrochlore & $(\mathrm{Na}, \mathrm{Ca})_{2} \mathrm{Nb}_{2} \mathrm{O}_{6}(\mathrm{OH}, \mathrm{F})$ & $4.2-6.4$ \\
\hline Fergusonite-(Y) & $\mathrm{YNbO}_{4}$ & 5.1 \\
\hline
\end{tabular}


Table 2. Ca, Sr, Mg and Ba gangue carbonates.

\begin{tabular}{ccc}
\hline Mineral & Formula & S.G. \\
\hline Calcite & $\mathrm{CaCO}_{3}$ & 2.7 \\
Dolomite & $\mathrm{CaMg}\left(\mathrm{CO}_{3}\right)_{2}$ & 2.9 \\
Siderite & $\mathrm{FeCO}_{3}$ & 3.8 \\
Strontianite & $\mathrm{SrCO}_{3}$ & 3.8 \\
Norsethite & $\mathrm{BaMg}\left(\mathrm{CO}_{3}\right)_{2}$ & 3.8 \\
Barytocalcite & $\mathrm{BaCa}\left(\mathrm{CO}_{3}\right)_{2}$ & 3.7 \\
Witherite & $\mathrm{BaCO}$ & 4.3 \\
Ankerite & $\mathrm{Ca}\left(\mathrm{Fe}^{2+}, \mathrm{Mg}, \mathrm{Mn}\right)\left(\mathrm{CO}_{3}\right)_{2}$ & 3.1 \\
\hline
\end{tabular}

Table 3. Other minor gangue minerals.

\begin{tabular}{ccccc}
\hline Mineral & Formula & S.G. & Magnetic Properties & Hardness \\
\hline Quartz & $\mathrm{SiO}_{2}$ & 2.6 & Diamagnetic & 7 \\
Chlorite & $\left(\mathrm{Mg}, \mathrm{Fe}^{2+}\right)_{5} \mathrm{Al}\left(\mathrm{Si}_{3} \mathrm{Al}\right) \mathrm{O}_{10}(\mathrm{OH})_{8}$ & $2.6-3.4$ & & $2-2.5$ \\
Pyrite & $\mathrm{FeS}_{2}$ & $4.9-5.0$ & Paramagnetic & $6-6.5$ \\
Sphalerite & $\mathrm{ZnS}$ & $3.9-4.2$ & Diamagnetic & $3.5-4$ \\
Cancrinite & $\mathrm{Na}_{6} \mathrm{Ca}_{2} \mathrm{Al}_{6} \mathrm{Si}_{6} \mathrm{O}_{24}\left(\mathrm{CO}_{3}\right)_{2}$ & 2.5 & & \\
Microcline & $\mathrm{KAlSi}_{3} \mathrm{O}_{8}$ & 2.6 & & \\
Nepheline & $\left(\mathrm{Na}_{2} \mathrm{~K} \mathrm{AlSiO}_{4}\right.$ & 2.7 & & \\
Sodalite & $\mathrm{Na}_{8}\left(\mathrm{Al}_{6} \mathrm{Si}_{6} \mathrm{O}_{24}\right) \mathrm{Cl}_{2}$ & 2.2 & & \\
\hline
\end{tabular}

Table 4. X-ray diffraction analysis of the head sample.

\begin{tabular}{|c|c|c|}
\hline Mineral & Quantity (\%) & Mineral chemical formula \\
\hline Ankerite/Dolomite (Mn) & 74.70 & $\mathrm{Ca}(\mathrm{Mg}, \mathrm{Fe}, \mathrm{Mn}) \mathrm{CO}_{3}$ \\
\hline Siderite & 9.10 & $\mathrm{FeCO}_{3}$ \\
\hline Quartz & 4.80 & $\mathrm{SiO}_{2}$ \\
\hline Calcite & 3.70 & $\mathrm{CaCO}_{3}$ \\
\hline Burbankite & 3.40 & $(\mathrm{Na}, \mathrm{Ca})_{3}(\mathrm{Sr}, \mathrm{Ba}, \mathrm{Ce})_{3}\left(\mathrm{CO}_{3}\right)_{5}$ \\
\hline Petersenite (Ce) & 1.70 & $\mathrm{Na}_{4} \mathrm{Ce}_{2}\left(\mathrm{CO}_{3}\right)_{5}$ \\
\hline Allanite-(Ce) & 1.10 & $\mathrm{Ca}_{1.26} \mathrm{Ce}_{0.74} \mathrm{Al}_{1.83} \mathrm{Fe}_{1.17}\left(\mathrm{SiO}_{4}\right)_{3}(\mathrm{OH})$ \\
\hline Biotite & 0.90 & $\mathrm{~K}\left(\mathrm{Mg}, \mathrm{Fe}^{2+}\right)_{3}\left[\mathrm{AlSi}_{3} \mathrm{O}_{10}(\mathrm{OH}, \mathrm{F})_{2}\right]$ \\
\hline Chlorite & 0.40 & $\left(\mathrm{Mg}, \mathrm{Fe}^{2+}\right)_{5} \mathrm{Al}\left(\mathrm{Si}_{3} \mathrm{Al}\right) \mathrm{O}_{10}(\mathrm{OH})_{8}$ \\
\hline Celestine-Ba & 0.20 & $(\mathrm{Sr}, \mathrm{Ba}) \mathrm{SO}_{4}$ \\
\hline Total & 100.00 & \\
\hline
\end{tabular}

Table 5. Head sample assay.

\begin{tabular}{cccccccccccccccc}
\hline \multicolumn{10}{c}{$\mathrm{Ce}_{2} \mathrm{O}_{3}$} & $\mathrm{Pr}_{2} \mathrm{O}_{3}$ & $\mathrm{Y}_{2} \mathrm{O}_{3}$ & $\mathrm{La}_{2} \mathrm{O}_{3}$ & $\mathrm{Nd}_{2} \mathrm{O}_{3}$ & $\mathrm{Dy}_{2} \mathrm{O}_{3}$ & TREO \\
\hline & 1.1 & 0.09 & 0.01 & 0.72 & 0.33 & 0.002 & 2.24 & & & & \\
$\mathrm{Nb}_{2} \mathrm{O}_{5}$ & $\mathrm{Al}_{2} \mathrm{O}_{3}$ & $\mathrm{Ba}_{2} \mathrm{O}_{3}$ & $\mathrm{CaO}$ & $\mathrm{Cr}_{2} \mathrm{O}_{3}$ & $\mathrm{Fe}_{2} \mathrm{O}_{3}$ & $\mathrm{~K}_{2} \mathrm{O}$ & $\mathrm{MgO}$ & $\mathrm{MnO}$ & $\mathrm{Na}_{2} \mathrm{O}$ & $\mathrm{P}_{2} \mathrm{O}_{5}$ & $\mathrm{SiO}_{2}$ & $\mathrm{TiO}_{2}$ & LOI \\
$\mathbf{0 . 3 1}$ & 0.98 & 4.87 & 17.87 & 0.01 & 20.62 & 0.75 & 7.65 & 2.1 & 1.66 & 0.2 & 5.91 & 0.8 & 31.01 \\
\hline
\end{tabular}


Yu et al. [7] conducted exploratory tests on this ore to compare the effects of collector type and dosage, grind fineness, and pulp temperature. They investigated several collectors such as: a fatty acid (Sylvat FA2), phosphoric acid ester (Clariant 1682), alkyl hydroxamate (Aero 6493), salicyl hydroximic acid, and T610, another variant of salicyl hydroximic acid manufactured in China. Despite the very good recovery of $73 \% \mathrm{Ce}_{2} \mathrm{O}_{3}$ (comparable to TREO recovery) in $22 \%$ of the mass, the recovery of $\mathrm{Nb}_{2} \mathrm{O}_{5}$ was poor, only $\sim 9 \%$. Additional investigations that employed a combination of gravity separation and flotation at a grind size of $80 \%-72 \mu \mathrm{m}$ did not achieve any benefit. Gravity separation alone yielded only $32 \% \mathrm{Nb}_{2} \mathrm{O}_{5}$ and $27 \% \mathrm{Ce}_{2} \mathrm{O}_{3}$ recovery in a concentrate accounting for $14 \%$ of the mass. Cleaning of the gravity concentrate using either gravity or magnetic separation was unsuccessful. Scavenging the gravity tailings by flotation, utilizing a combination of fatty acid and alkyl hydroxamate collectors and sodium silicate and carboxyl methylcellulose (CMC) depressants, resulted in $84 \% \mathrm{Nb}_{2} \mathrm{O}_{5}$ and $74 \% \mathrm{Ce}_{2} \mathrm{O}_{3}$ recovery in a combined gravity and flotation concentrate in $43 \%$ of the mass. The gravity concentration amenability tests conducted using Wilfley Table, Mozley Table, Falcon Enhanced Gravity Concentrator, and heavy media separations did not yield results comparable to those obtained by flotation.

The current investigation achieved higher than 92\% TREO and $\mathrm{Nb}$ recoveries at $45 \%$ mass pull using flotation only. Regrinding the concentrate before cleaning did result in significant upgrading but at reduced recoveries. The rougher and scavenger flotation concentrates were combined and submitted to SGS Lakefield for hydrometallurgical processing. Lixiviation of the concentrate using hydrochloric acid yielded REE extractions of $\sim 99 \%$. An overall (from ore in the ground to final precipitate) REE recovery of $80 \%$ was obtained through a series of selective precipitation steps.

This paper presents the advancements made in improving the physical separation conditions and upgrading the flotation concentrates by using magnetizing calcination followed by concentrate regrind and magnetic separation techniques.

\section{Experimental}

The effects of reagents, reagent addition points, $\mathrm{pH}$, pulp de-sliming, conditioning intensity, particle size distributions and temperature were studied using a 1 $\mathrm{kg}$ sample wet ground to a $\mathrm{d}_{80}$ of $37 \mu \mathrm{m}$ at $66 \%$ solids. Both $\mathrm{pH}$ and temperature were monitored and tightly controlled. After several reagent combinations were tested, alkyl hydroxamic acid (collector), Na-silicate (dispersant), and carboxymethyl cellulose (depressant) were found to have the right synergy to recover both the REE- and Nb-bearing minerals. The collector used was the Aero 6493 supplied by Cytec and the dispersant was the sodium metasilicate pentahydrate $\left(\left(\mathrm{Na}_{2} \mathrm{SiO}_{3} \cdot 5 \mathrm{H}_{2} \mathrm{O}\right)\right.$. The depressant $(\mathrm{CMC})$ used was $\mathrm{C}_{8} \mathrm{H}_{15} \mathrm{NaO}_{8}(\mathrm{DS}=0.7)$ and supplied by Fisher Scientific. Although no collector exists synthesized to float all the different rare earth minerals and Nb-bearing minerals concurrently, the alkyl hydroxamic acid has shown adequate efficiency of floating most of these miner- 
als. Due to the frothing characteristics of the collector, no additional frother was needed.

The flotation concentrate obtained under optimum grind size and flotation chemistry after multiple reagents and flotation investigations was calcined, reground to a $d_{80}$ of $25 \mu \mathrm{m}$ and magnetically upgraded.

\section{Equipment}

A modified flotation vessel ( $2.75 \mathrm{~L}$ volume) with a froth crowding dome and a forward froth deflecting plate was fitted to a Denver agitation system to allow unassisted and unrestricted concentrate froth flow (Figure 1). $0.5 \mathrm{~L} / \mathrm{min}$ of airflow and agitation speed of $1200 \mathrm{rpm}$ was used throughout the experiment. Due to the new cell design, pulp level control was neither required nor desired as it dilutes the pulp unnecessarily. Timed flotation using this flotation system accurately predicts both metal recovery and mass pull when the well-known flotation kinetics model (Equation (1)) is used. $R_{t}$ is a recovery or mass pull at time $t, k$ is a flotation rate constant, and $R_{\infty}$ is a recovery or mass pull at infinite time.

$$
R_{t}=R_{\infty}\left(1-e^{-k_{t}}\right)
$$

Calcination of flotation concentrate was carried in a small benchtop temperature-controlled furnace. The furnace was preheated to the set temperature before a sample loaded into a ceramic crucible was introduced. The furnace cavity was open to the atmosphere through a $2.5 \mathrm{~cm}$ diameter hole at the top of the furnace. The magnetic separator (Figure 2) consists of two sets of magnetic blocks separated by a canister with their north poles oriented towards each other. The canister was designed to take either a ferromagnetic wire-mesh pad or balls. The gap between the magnets was set using a crankshaft driven, left- and right-hand threaded long screw to which the two blocks of magnets are connected. It was possible to create the intensity and gradient suitable for the separation of this ore

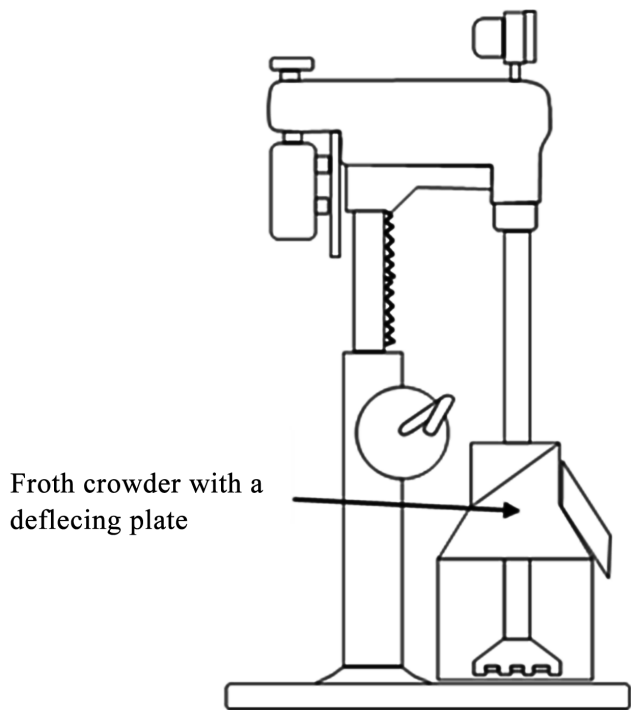

Figure 1. Modified Denver flotation cell. 


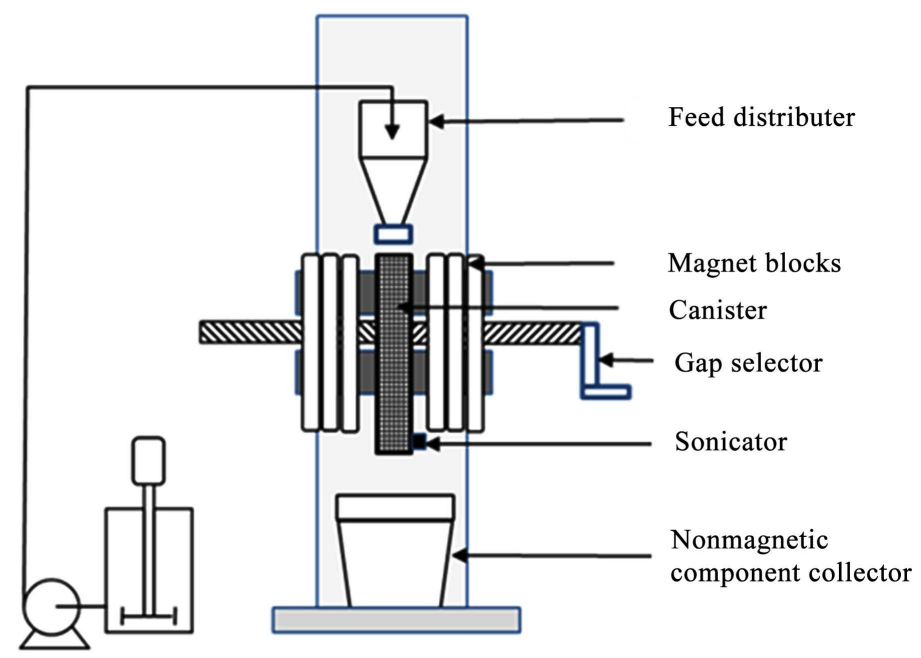

Figure 2. Low-intensity high-gradient magnetic separator.

in a manner that was not possible with commercial LIMS and HGMS laboratory equipment. The variable gap, the mesh size, and the ball size create continuous infinite intensity and gradient settings within the natural limit of the magnets' strength. At the narrowest gap $(1.5 \mathrm{~cm})$ between the two sets of magnets, the maximum magnetic flux density generated at the empty canister centre was 2.4 $\mathrm{kGauss}$. The feed ( 50 to $60 \mathrm{~g}$ ) was suspended in $250 \mathrm{~mL}$ of water and pumped to the matrix-filled canister at a rate of $100 \mathrm{~mL} / \mathrm{min}$. At the end of the separation, the canister was rinsed with $250 \mathrm{~mL}$ of water. To minimize particle entrapment within the voids in the magnetic particles bed, the canister was sonicated with a mechanical device.

\section{Results and Discussions}

\subsection{Flotation}

Since Ce's recovery was about the same as that of the total rare earth oxide (TREO) for this ore, only the recovery of Ce was plotted. This does not imply that the recovery of the individual REEs was equivalent to that of Ce.

\subsubsection{Reagent Addition Sequence}

Figure 3 and Figure 4 show the effect of the reagent addition sequence; $1243 \mathrm{~g} / \mathrm{t}$ Aero 6493, $850 \mathrm{~g} / \mathrm{t} \mathrm{Na}$-silicate, and $430 \mathrm{~g} / \mathrm{t}$ of CMC additions were used for these experiments. No frother was required. The pulp was conditioned for three minutes with a collector and two minutes each with Na-silicate and CMC. The total flotation time was 15 minutes. Besides the reagents themselves, the most critical parameter was the addition sequence. The pulp was normally first conditioned with depressants and then with the appropriate collector to achieve acceptable separation of valuable minerals from the gangue. In this case, however, such a strategy resulted in significantly less REE and $\mathrm{Nb}$ minerals separation, as shown in Figure 3 and Figure 4. Hence, for this ore, the reagent addition sequences were reversed. 


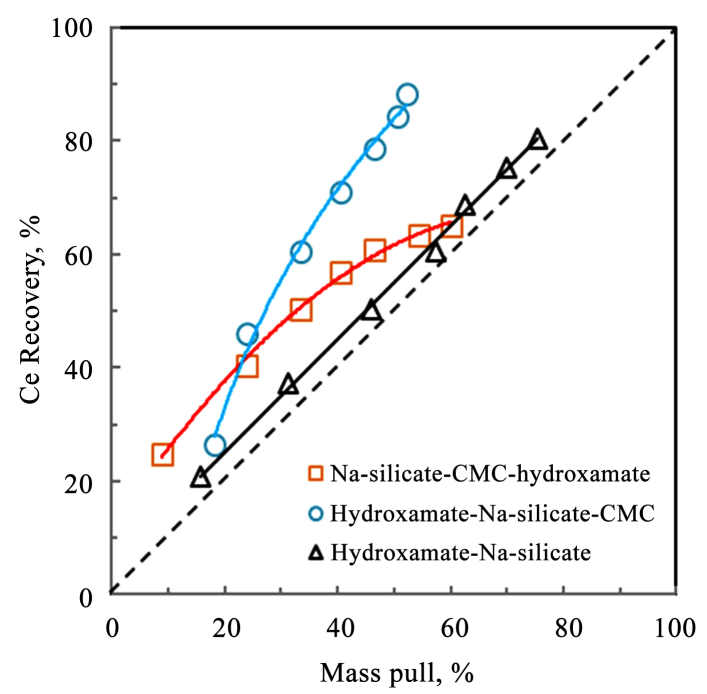

Figure 3. Effect of reagents addition sequence on Ce recovery.

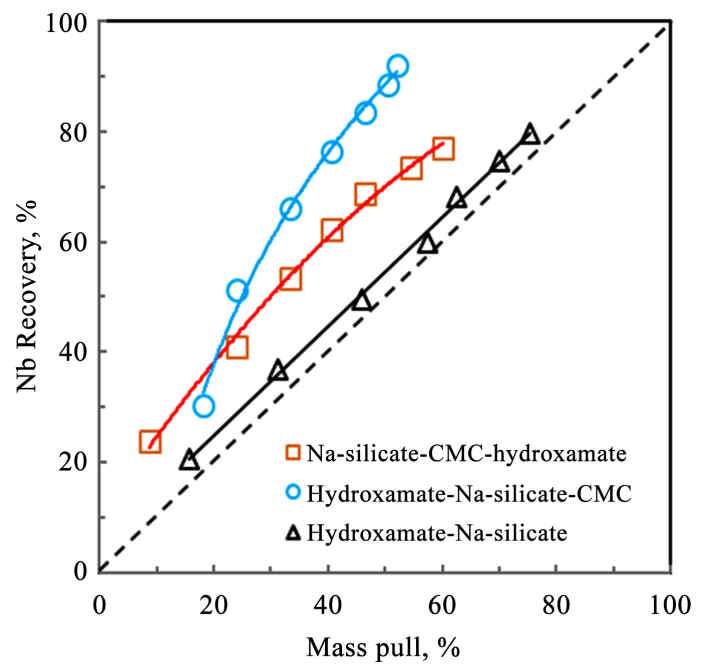

Figure 4. Effect of reagents addition sequence on $\mathrm{Nb}$ recovery.

In the absence of CMC, there is practically no REEs or $\mathrm{Nb}$ separation. At $50 \%$ mass pull, $\mathrm{Ce}$ and $\mathrm{Nb}$ recoveries were $\sim 21 \%$ higher when the pulp was conditioned with collector first and then with depressants.

\subsubsection{Effects of Na-Silicate and CMC}

Figure 5 and Figure 6 show the effects of Na-silicate and CMC when applied separately. In the absence of CMC, there was practically no separation of either REE or Nb minerals. However, in the absence of Na-silicate, both REE and $\mathrm{Nb}$ minerals' separation was significant, more so for $\mathrm{Nb}$ minerals. At $50 \%$ mass pull, REEs and $\mathrm{Nb}$ recoveries are about $62 \%$ and $75 \%$, respectively. This implies that $\mathrm{Na}$-silicate by itself had very little effect on the separation of the REE and $\mathrm{Nb}$ minerals from the gangue. Its primary role appears to enhance the effect of CMC shown in Figure 5 and Figure 6. In the presence of both Na-silicate and CMC the $\mathrm{Ce}$ and $\mathrm{Nb}$ recoveries at $50 \%$ mass pull were $86 \%$ and $90 \%$, respectively. 


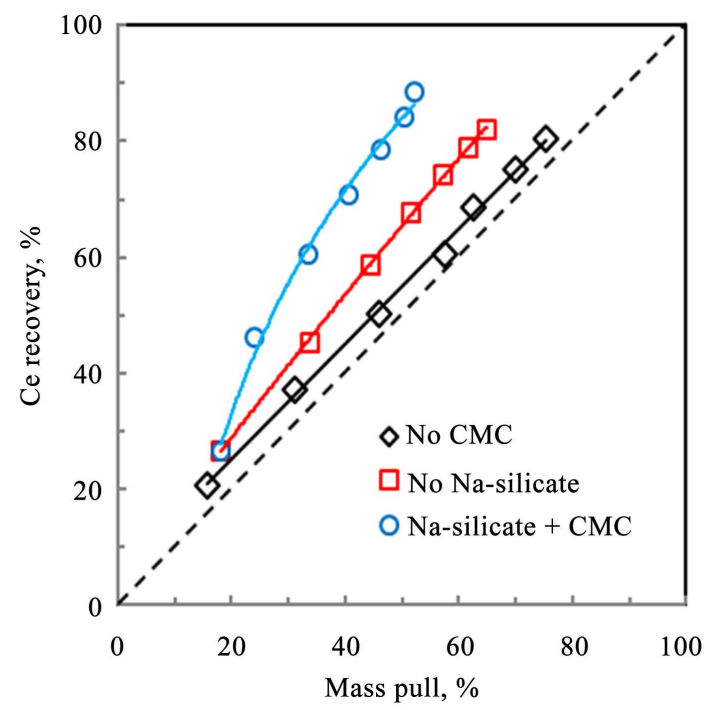

Figure 5. Synergetic effects of CMC and Na-silicate on Ce recovery.

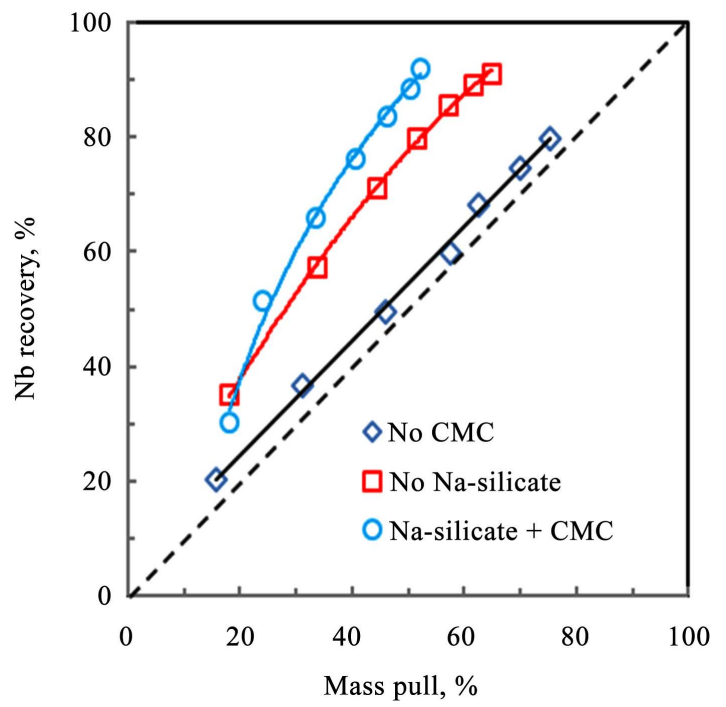

Figure 6. Synergetic effects of $\mathrm{CMC}$ and $\mathrm{Na}$-silicate on $\mathrm{Nb}$ recovery.

\subsubsection{Flotation Pulp De-Sliming}

The flotation pulp was de-slimed before and after it was conditioned with reagents (i.e. before flotation) to improve separation performance. As shown in Figure 7 and Figure 8, de-sliming of the pulp after grinding (i.e. before conditioning with reagents) significantly reduced the separation of REE and $\mathrm{Nb}$ minerals from the gangue minerals. At 50\% mass pull, $\mathrm{Ce}$ and $\mathrm{Nb}$ recoveries dropped from $82 \%$ and $90 \%$ to $60 \%$ and $66 \%$, respectively. Whereas it did not influence Ce recovery, de-sliming after conditioning with reagents improved $\mathrm{Nb}$ recovery significantly, as seen in Figure 8.

\subsubsection{CMC Dosage}

An increase in CMC addition from $430 \mathrm{~g} / \mathrm{t}$ to $645 \mathrm{~g} / \mathrm{t}$ decreased the Ce and $\mathrm{Nb}$ recoveries by $20 \%$ at $50 \%$ mass pull (Figure 9 and Figure 10). 


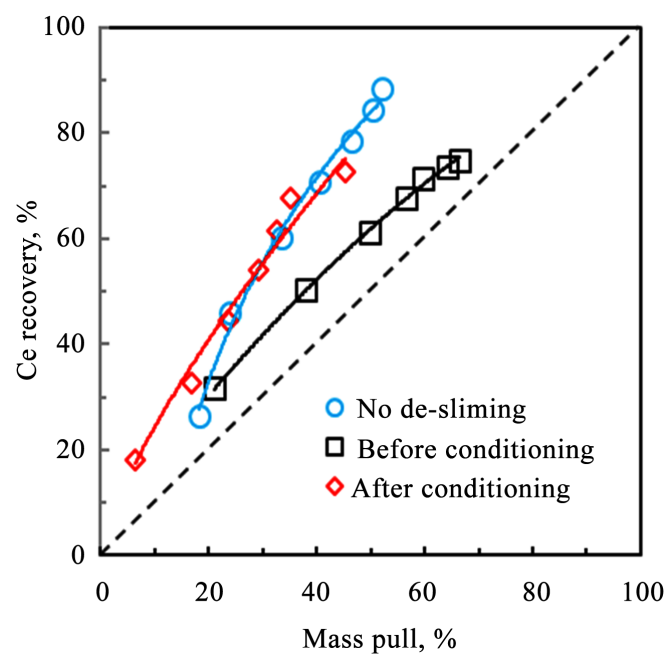

Figure 7. Effect of de-sliming on Ce recovery.

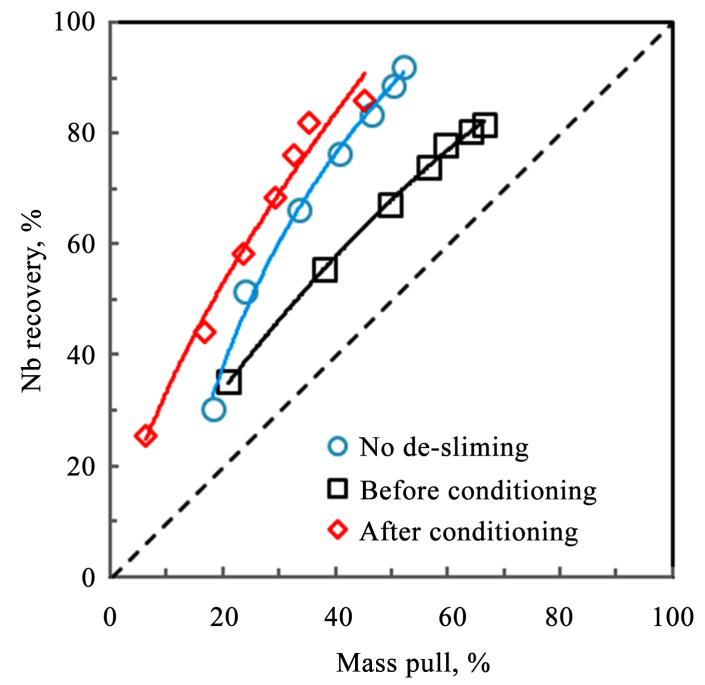

Figure 8. Effect of de-sliming on $\mathrm{Nb}$ recovery.

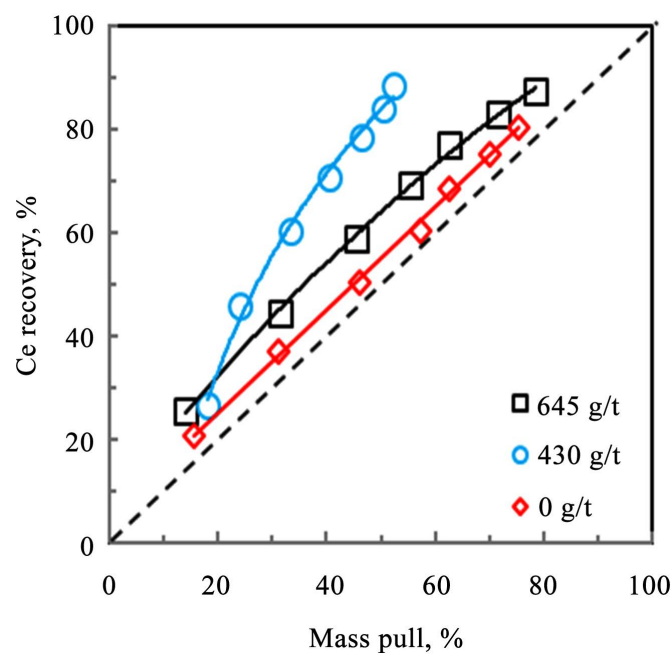

Figure 9. Effect of CMC dosage on Ce recovery. 


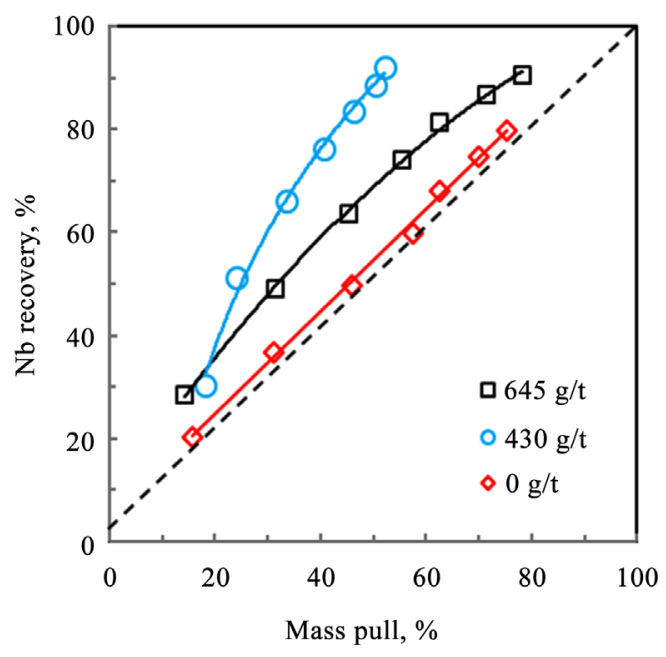

Figure 10. Effect of CMC dosage on $\mathrm{Nb}$ recovery.

\subsubsection{Flotation Pulp Temperature}

An increase in the pulp temperature had a negative effect on separation efficiency as shown in Figure 11 and Figure 12. While it is apparent for this fine grind that the separation efficiency would be hampered with an increase in pulp temperature, increasing the temperature had a negligible effect for a coarser grind of $\mathrm{d}_{80} \sim 63 \mu \mathrm{m}$ (not plotted).

\subsubsection{Conditioning Intensity}

Whereas the effect of conditioning intensity on Ce recovery was only marginal (Figure 13), it did improve the separation of Nb significantly (Figure 14), lowering the mass pull for a given recovery.

\subsubsection{Particle Size Distribution}

At a coarser grind size of $\mathrm{d}_{80} \sim 63 \mu \mathrm{m}$, both Ce and $\mathrm{Nb}$ separation efficiencies dropped significantly under these flotation conditions (Figure 15 and Figure $16)$.

\subsubsection{Pulp pH}

The recoveries of both $\mathrm{Ce}$ and $\mathrm{Nb}$ were strongly dependent on $\mathrm{pH}$ and sharply improved with an increase in $\mathrm{pH}$ as shown in Figure 17.

\subsection{Distributed Addition of Reagents}

A multi-step sequential collector-depressant conditioning was adopted (Figure 18 and Table 6) to enhance REE and $\mathrm{Nb}$ minerals' recoveries. Under these conditions, it was possible to increase the grind size to $\mathrm{d}_{80} \sim 63 \mu \mathrm{m}$. The data plotted in Figure 19 and Figure 20 are the results of five 2-kg tests conducted to produce enough concentrate for further upgrading studies and verify the flotation process repeatability. This strategy made it possible to obtain precisely the same separation efficiencies and recoveries for both TREO and Nb, $92 \%$ recovery at $45 \%$ mass pull with excellent repeatability as indicated in Figure 19 and Figure 20. 


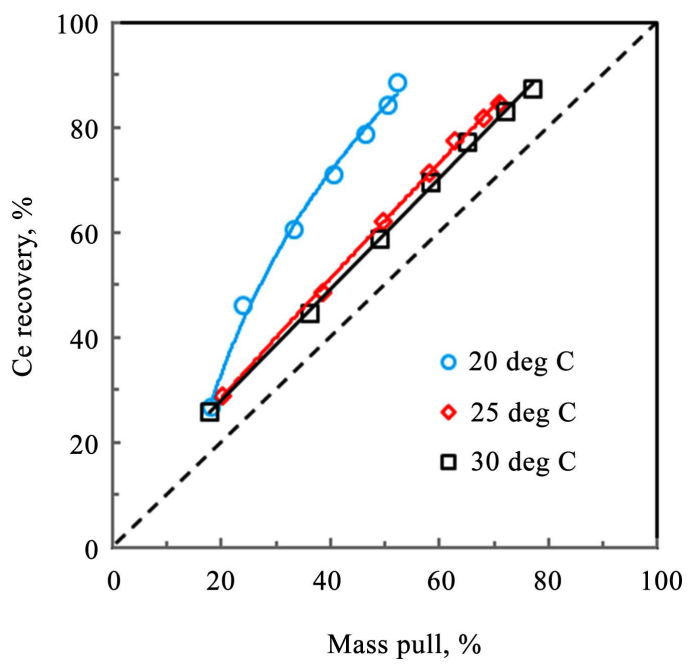

Figure 11. Effect of temperature on Ce recovery.

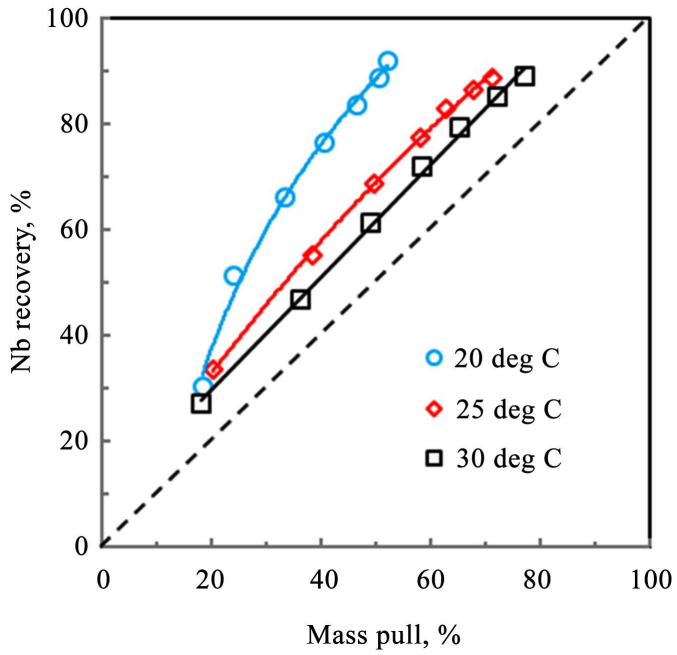

Figure 12. Effect of temperature on $\mathrm{Nb}$ recovery.

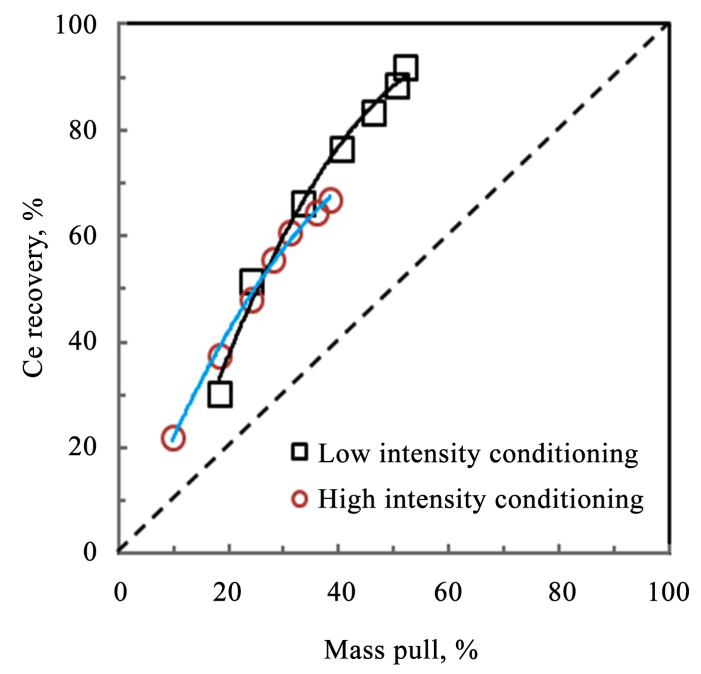

Figure 13. Effect of conditioning intensity on Ce recovery. 


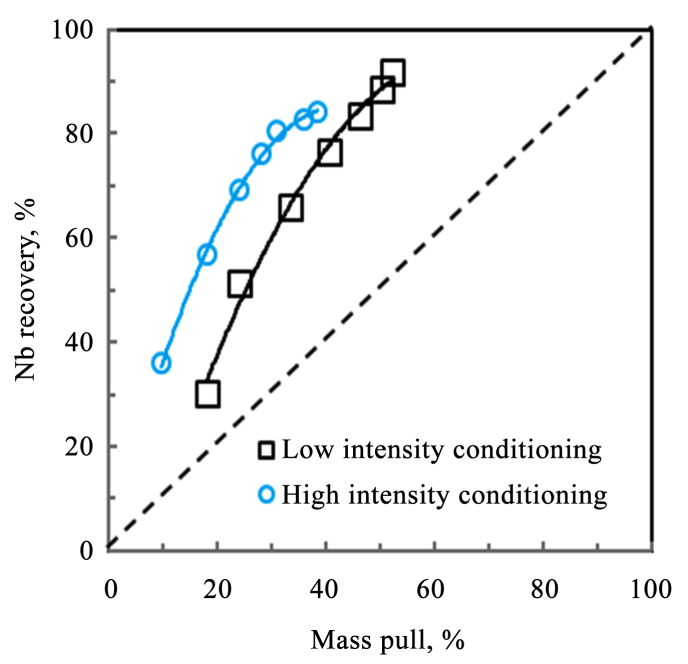

Figure 14. Effect of conditioning intensity on $\mathrm{Nb}$ recovery.

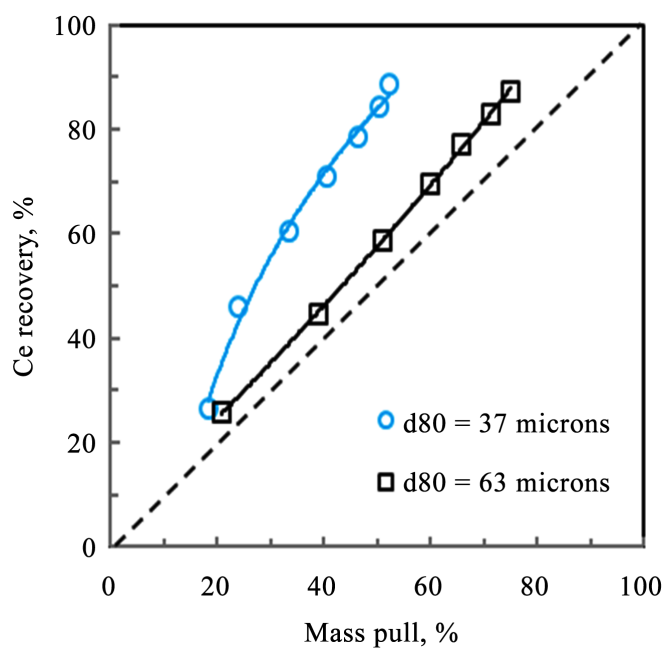

Figure 15. Effect of particle size distribution on Ce recovery.

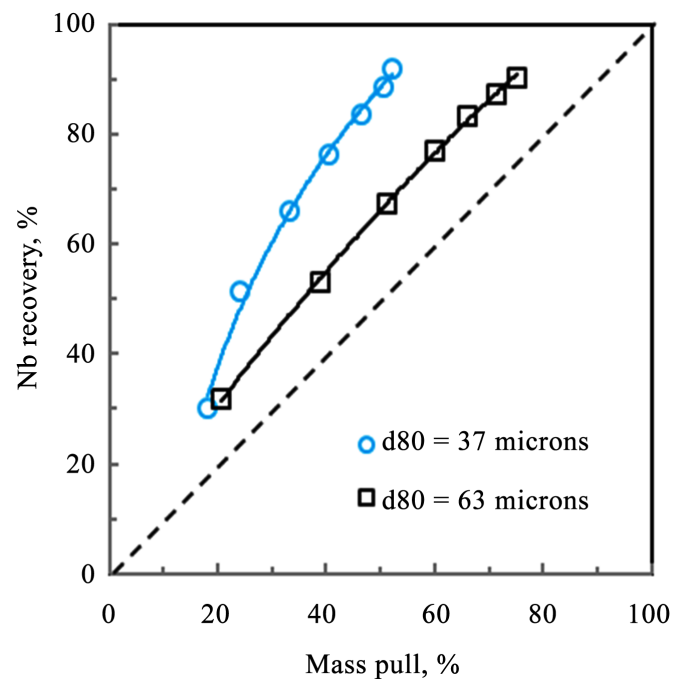

Figure 16. Effect of particle size distribution on $\mathrm{Nb}$ recovery. 


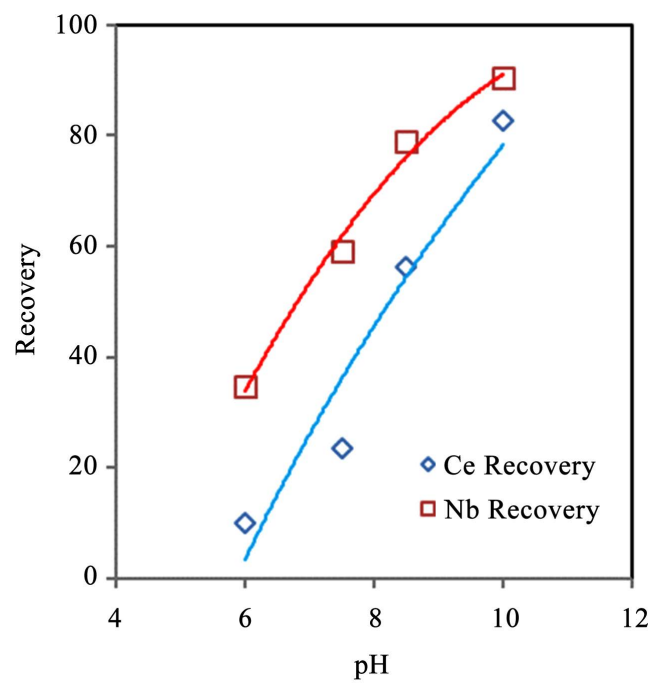

Figure 17. Effect of $\mathrm{pH}$ on $\mathrm{Ce}$ and $\mathrm{Nb}$ recovery.

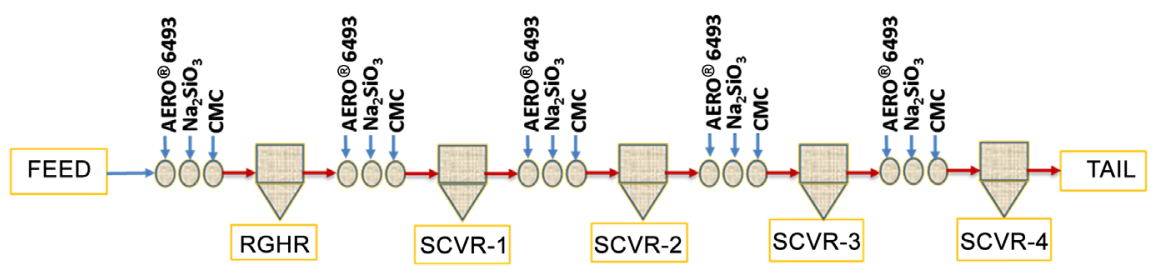

Figure 18. Reagent addition sequences and conditioning scheme.

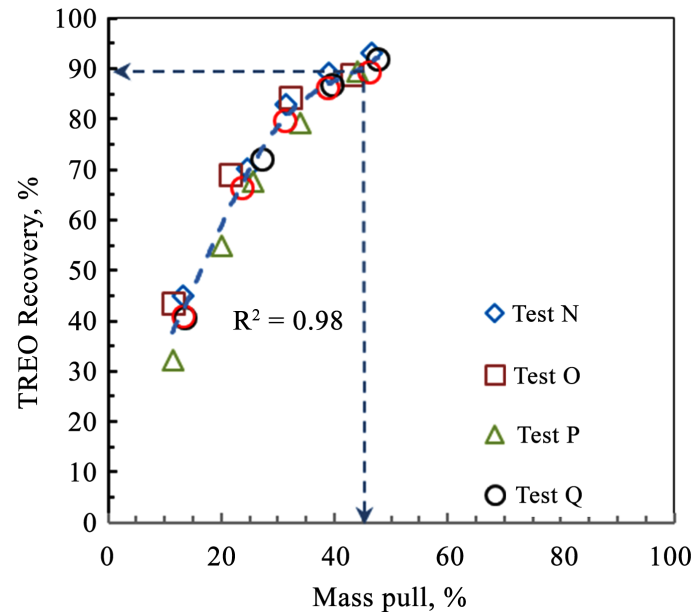

Figure 19. TREO recovery/separation enhancement with stage conditioning and flotation.

Table 6. Reagent conditions.

\begin{tabular}{cccccc}
\hline & \multicolumn{5}{c}{ Reagent, g/t } \\
\cline { 2 - 6 } & RGHR & SCVR-1 & SCVR-2 & SCVR-3 & SCVR-4 \\
\hline Aero 6493 & 732 & 537 & 244 & 341 & 341 \\
Na-silicate & 675 & 289 & 289 & 96 & 675 \\
CMC & 341 & 146 & 98 & 98 & 49 \\
\hline
\end{tabular}




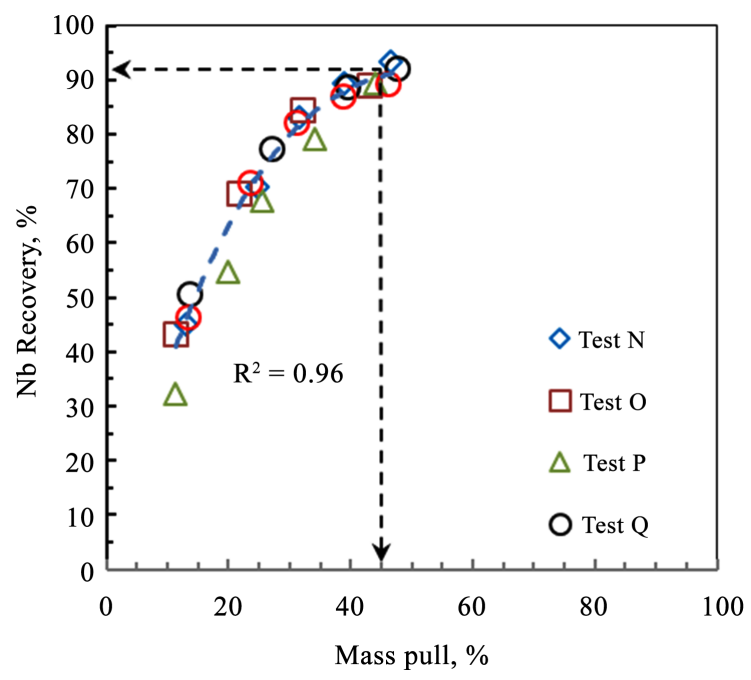

Figure 20. Nb recovery/separation enhancement with stage conditioning and flotation.

\section{Flotation Concentrate Upgrading}

Despite the successful enhancement of both the recovery and separation efficiency, the concentrate did not respond to cleaning by flotation due to the high level of reagent used. Up to 3-fold concentrate upgrading was possible using conventional gravity separation equipment such as the Mozley or the Gemeni Tables, but the recovery loss remained high. Because of this, a systematic investigation was conducted to upgrade the concentrate with magnetic separation. Both conventional LIMS and HGMS resulted in significant separation but not satisfactory recovery.

Regrinding of the concentrate to $\mathrm{d}_{80} 37 \mu \mathrm{m}$ improved the simultaneous separation of REE and $\mathrm{Nb}$ minerals from the gangue, but the recovery remained low. Subsequently, calcination of the flotation concentrates at temperatures varying from $750^{\circ} \mathrm{C}$ to $900^{\circ} \mathrm{C}$ for four hours was explored as shown in Figure 21 and Figure 22. The results shown in both figures were obtained only after the calcined concentrate was reground to $\mathrm{d}_{80}$ of $\sim 37 \mu \mathrm{m}$ and magnetically upgraded. The recovery-mass pull profile was generated from the cumulative mass balance following separations at four inter-magnet pole gaps (i.e. four magnetic intensity levels). The concentrate was the non-magnetic component of the separator. The magnetic separation efficiency improved with increasing intensity at the cost of recovery. Within the calcination temperature range studied $\left(750^{\circ} \mathrm{C}-900^{\circ} \mathrm{C}\right)$, the separation efficiency improved with increasing calcination temperature. Since the flotation concentration obtained $45 \%$ mass pull and $92 \%$ recovery for both REEs and $\mathrm{Nb}$ (Figure 19 and Figure 20), if a 35\% mass pull of the magnetic separation was taken as the optimal cut-off (Figure 21 and Figure 22), the overall recovery of REEs will be $87.4 \%$ at the overall mass pull of $15.8 \%$. The overall recovery of $\mathrm{Nb}$ would be slightly lower at $84.7 \%$. The hybrid flotation-calcinationregrind-magnetic separation flowsheet is shown in Figure 23. The average mass loss during calcination was about $30 \%$. 


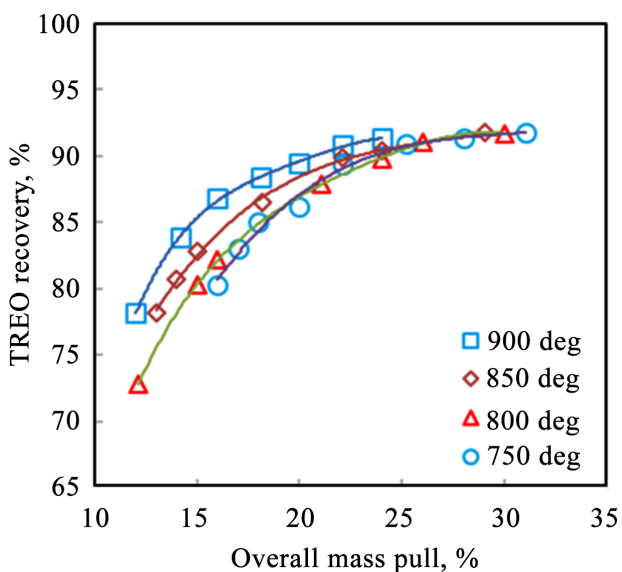

Figure 21. Effects of concentrate calcination temperature on magnetic separation of TREO.

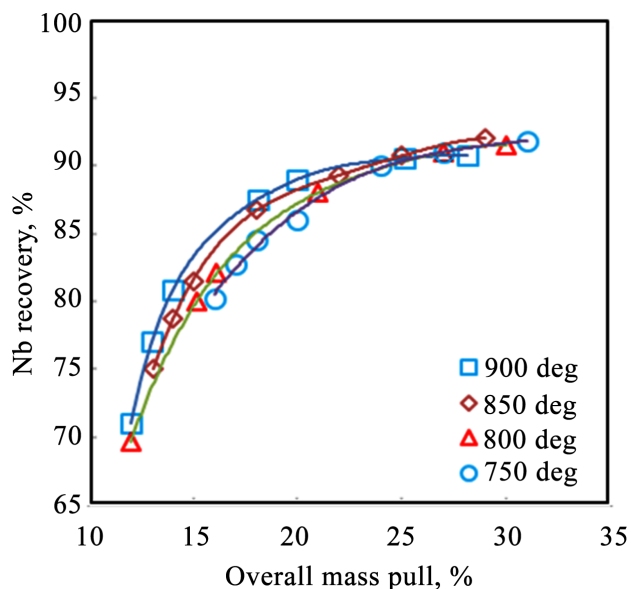

Figure 22. Effects of concentrate calcination temperature on magnetic separation of $\mathrm{Nb}$.

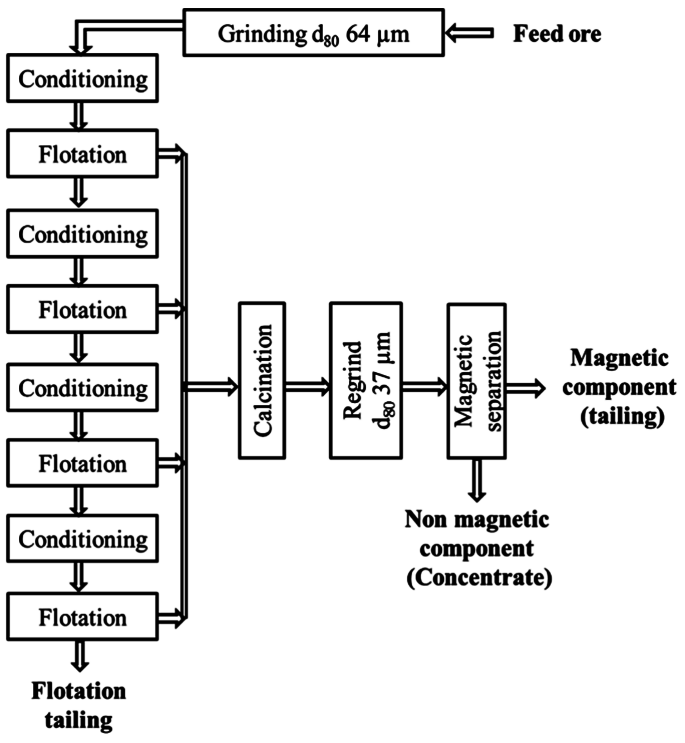

Figure 23. Grinding, conditioning, flotation, calcinations and magnetic separation flowsheet. 


\section{Conclusions}

Several reagents were tested separately and concurrently to separate the major REE-bearing minerals namely kukharonkite $\left(\mathrm{Ba}_{2} \mathrm{REE}\left(\mathrm{CO}_{3}\right)_{3} \mathrm{~F}\right)$, burbankite [ $\mathrm{Na}$, $\left.\mathrm{Ca})_{3}(\mathrm{Sr}, \mathrm{Ba}, \mathrm{Ce})_{3}\left(\mathrm{CO}_{3}\right)_{5}\right]$ and cebaite $\left[\mathrm{Ba}_{3} \mathrm{Ce}_{2}\left(\mathrm{CO}_{3}\right) 5 \mathrm{~F}_{2}\right]$ as well as Nb-minerals (pyrochlore and fergusonite) from the predominantly carbonate gangue minerals. Although kukharonkite and cebaite belong to the same family as bastnaesite, they proved irresponsive to all collectors known to have been used for its flotation except the alkyl hydroxamate. There were several notably unique flotation characteristics of this ore as determined using the timed flotation technique:

1) The customary flotation process sequence of conditioning with depressants first and then with collectors did not result in any concentration of value minerals. Meaningful separation could only be obtained when the sequence was reversed despite high collector consumption.

2) Among several depressant-collector combinations tested, only alkyl hydroxamic acid, sodium silicate, and CMC proved to work.

3) The role of CMC, as expected, is depressing the gangue which has already been exposed to a collector.

4) Sodium silicate is commercially used as a depressant or dispersant. For this ore, CMC's depressing effect in the absence of prior conditioning of the pulp with sodium silicate was insignificant. Besides, in the absence of CMC, sodium silicate does not exhibit any characteristics of a depressant. This proves that sodium silicate in and of itself does not possess the ability to depress the gangue. Its role was most probably dispersing the fine particles, thus creating favourable conditions for CMC adsorption. Sodium silicate does also play a significant role in controlling the $\mathrm{pH}$ due to its buffering capacity.

5) For the fine grind of $d_{80} \sim 37 \mu \mathrm{m}$, under the timed flotation scheme (single-stage sequential conditioning with sodium silicate followed by $\mathrm{CMC}$ ) the effect of pulp temperature variation between $20^{\circ} \mathrm{C}$ and $30^{\circ} \mathrm{C}$ was very significant. The separation efficiency drops significantly with increasing pulp temperature. At the coarser grind of $\mathrm{d}_{80} \sim 63 \mu \mathrm{m}$ and multiple stage conditioning (with alkyl hydroxamate, sodium silicate, and $\mathrm{CMC}$ ) and multiple stage scavenger flotation, the effect of temperature in this range became negligible.

6) Under the timed-flotation scheme, both REE and Nb minerals' separation efficiencies were superior for the fine grind of $\mathrm{d}_{80} 37 \mu \mathrm{m}$ compared to the coarser grind of $\mathrm{d}_{80} 63 \mu \mathrm{m}$. Interestingly, under the multi-stage conditioning and flotation, the coarser grind yielded the best separation, grades, and recoveries for both REE and $\mathrm{Nb}$ minerals. Of course, under this scheme, significantly more reagents were consumed.

7) De-sliming of the pulp before reagent additions reduced the separation efficiency. However, de-sliming of the pulp after conditioning favoured the increase in $\mathrm{Nb}$ recovery with no significant effect on REE minerals' recovery.

8) Similarly, high-intensity pulp conditioning positively affected $\mathrm{Nb}$ minerals recovery without significant effects on REE minerals. 
9) The flotation recovery of both $\mathrm{REE}$ and $\mathrm{Nb}$ minerals was strongly dependent on $\mathrm{pH}$. Within the $\mathrm{pH}$ range investigated $(\mathrm{pH} 6$ to $\mathrm{pH} 10)$, the separation of $\mathrm{REE}$ and $\mathrm{Nb}$ minerals sharply improves with an increase in $\mathrm{pH}$.

10) To enhance the bulk recovery of REE and $\mathrm{Nb}$ minerals, while at the same time decreasing the mass pull, a multi-step sequential collector-depressant conditioning was adopted. Under these conditions, it was possible to increase the grind size to $\mathrm{d}_{80} \sim 63 \mu \mathrm{m}$. This strategy made it possible to obtain precisely the same separation efficiencies and recoveries for both TREO and $\mathrm{Nb}, 92 \%$ recovery at $45 \%$ mass pull with excellent repeatability.

11) The hybrid flotation-calcination-regrind-magnetic separation flowsheet developed resulted in overall $87.4 \%$ and $84.7 \%$ recoveries of TREO and $\mathrm{Nb}$, respectively, in $15.8 \%$ mass pull. This was only made possible by the magnetic separator suitable for selecting a variable range of magnetic field intensity and gradient to process a very fine $\left(\mathrm{d}_{80} 25 \mu \mathrm{m}\right)$ mainly liberated mineral particles.

\section{Acknowledgements}

The author would like to express appreciation to Natural Resources Canada and GeoMegA Resources for the research's financial and material support.

\section{Conflicts of Interest}

The author declares no conflicts of interest regarding the publication of this paper.

\section{References}

[1] Dushyantha, N., Batapola, N., Ilankoon, I.M.S.K., Rohitha, S., Premasiri, R., Abeysinghe, B., Ratnayake, N. and Dissanayake, K. (2020) The Story of Rare Earth Elements (REEs): Occurrences, Global Distribution, Genesis, Geology, Mineralogy and Global Production. Ore Geology Reviews, 122, Article ID: 103521.

https://doi.org/10.1016/j.oregeorev.2020.103521

[2] Farisa, N., et al. (2019) Characterisation of a Ferruginous Rare Earth Bearing Lateritic Ore and Implications for Rare Earth Mineral Processing. Minerals Engineering, 134, 23-36. https://doi.org/10.1016/j.mineng.2019.01.019

[3] Pradip, D. and Fuerstenau, W. (1991) The Role of Inorganic and Organic Reagents in the Flotation Separation of Rare-Earth Ores. International Journal of Mineral Processing, 32, 1-22. https://doi.org/10.1016/0301-7516(91)90016-C

[4] Weng, Z., Simon, M.J., Gavin, M.M. and Haque, N. (2015) A Detailed Assessment of Global Rare Earth Element Resources: Opportunities and Challenges. Society of Economic Geologists, 110, 1925-1952. https://doi.org/10.2113/econgeo.110.8.1925

[5] Verplanck, P.L. and Van Gosen, B.S. (2011) Carbonatite and Alkaline Intrusion-Related Rare Earth Element Deposits-A Deposit Model: U.S. Geological Survey Open-File Report 2011-1256, 6 p. https://doi.org/10.3133/ofr20111256

[6] Nadeau, O., Cayer, A., Pelletier, M., Stevenson, R. and Jébrak, M. (2015) The Paleoproterozoic Montviel Carbonatite-Hosted REE-Nb Deposit, Abitibi, Canada: Geology, Mineralogy, Geochemistry and Genesis. Ore Geology Reviews, 67, 314-335. https://doi.org/10.1016/j.oregeorev.2014.12.017

[7] Yu, B., Verbaan, N., Pearse, G. and Britt, S. (2013) Beneficiation and Extraction of 
REE from GeoMegA Resources' Montviel Project. In: London, I.M., Goode, J.R., Moldoveanse, G., Reyat, M.S., Eds., Rare Earths, Proceedings of the 51 st Annual Conference of Metallurgists of CIM (COM 2013), Westmount, QC, Canada, 215-229. 